May 2002 • NREL/CP-520-31429

\title{
High-Efficiency Polycrystalline CdTe Thin-Film Solar Cells with an Oxygenated Amorphous CdS (a-CdS:O) Window Layer
}

\section{Preprint}

X. Wu, R.G. Dhere, Y. Yan, M.J. Romero, Y. Zhang, J. Zhou, C. DeHart, A. Duda, C. Perkins, and B. To

To be presented at the $29^{\text {th }}$ IEEE PV Specialists Conference New Orleans, Louisiana May 20-24, 2002

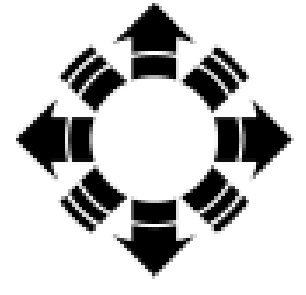

\section{NPEI}

National Renewable Energy Laboratory

1617 Cole Boulevard

Golden, Colorado 80401-3393

NREL is a U.S. Department of Energy Laboratory

Operated by Midwest Research Institute • Battelle • Bechtel

Contract No. DE-AC36-99-G010337 


\section{NOTICE}

The submitted manuscript has been offered by an employee of the Midwest Research Institute (MRI), a contractor of the US Government under Contract No. DE-AC36-99G010337. Accordingly, the US Government and MRI retain a nonexclusive royalty-free license to publish or reproduce the published form of this contribution, or allow others to do so, for US Government purposes.

This report was prepared as an account of work sponsored by an agency of the United States government. Neither the United States government nor any agency thereof, nor any of their employees, makes any warranty, express or implied, or assumes any legal liability or responsibility for the accuracy, completeness, or usefulness of any information, apparatus, product, or process disclosed, or represents that its use would not infringe privately owned rights. Reference herein to any specific commercial product, process, or service by trade name, trademark, manufacturer, or otherwise does not necessarily constitute or imply its endorsement, recommendation, or favoring by the United States government or any agency thereof. The views and opinions of authors expressed herein do not necessarily state or reflect those of the United States government or any agency thereof.

Available electronically at http://www.osti.gov/bridge

Available for a processing fee to U.S. Department of Energy and its contractors, in paper, from:

U.S. Department of Energy

Office of Scientific and Technical Information

P.O. Box 62

Oak Ridge, TN 37831-0062

phone: 865.576 .8401

fax: 865.576.5728

email: reports@adonis.osti.gov

Available for sale to the public, in paper, from:

U.S. Department of Commerce

National Technical Information Service

5285 Port Royal Road

Springfield, VA 22161

phone: 800.553 .6847

fax: 703.605.6900

email: orders@ntis.fedworld.gov

online ordering: http://www.ntis.gov/ordering.htm

Printed on paper containing at least $50 \%$ wastepaper, including $20 \%$ postconsumer waste 


\title{
HIGH-EFFICIENCY POLYCRYSTALLINE CdTe THIN-FILM SOLAR CELLS WITH AN OXYGENATED AMORPHOUS CdS (a-CdS:O) WINDOW LAYER
}

\author{
X. Wu, R.G. Dhere, Y. Yan, M.J. Romero, Y. Zhang, J. Zhou, C. DeHart, A. Duda, C. Perkins, and B. To \\ National Renewable Energy Laboratory, 1617 Cole Blvd., Golden, CO 80401
}

\begin{abstract}
In the conventional CdS/CdTe device structure, the poly-CdS window layer has a bandgap of $\sim 2.4 \mathrm{eV}$, which causes absorption in the short-wavelength region. Higher short-circuit current densities $\left(\mathrm{J}_{\mathrm{sc}}\right)$ can be achieved by reducing the CdS thickness, but this can adversely impact device open-circuit voltage $\left(\mathrm{V}_{\mathrm{oc}}\right)$ and fill factor $(\mathrm{FF})$. Also, poly-CdS film has about $10 \%$ lattice mismatch related to the CdTe film, which limits the improvement of device $\mathrm{V}_{\mathrm{oc}}$ and FF. In this paper, we report a novel window material: oxygenated amorphous CdS film (a-CdS:O) prepared at room temperature by rf sputtering. The a-CdS:O film has a higher optical bandgap (2.5-3.1 eV) than the poly-CdS film and an amorphous structure. The preliminary device results have demonstrated that $\mathrm{J}_{\mathrm{sc}}$ of the CdTe device can be greatly improved while maintaining higher $V_{\text {oc }}$ and FF. We have fabricated a CdTe cell demonstrating an NRELconfirmed $\mathrm{J}_{\mathrm{sc}}$ of $25.85 \mathrm{~mA} / \mathrm{cm}^{2}$ and a total-area efficiency of $15.4 \%$.
\end{abstract}

\section{INTRODUCTION}

Cadmium telluride (CdTe) has been recognized as a promising photovoltaic material for thin-film solar cells because of its near-optimum bandgap of $\sim 1.5 \mathrm{eV}$ and its high absorption coefficient. Small-area CdTe cells with efficiencies of more than $16 \%$ and commercial-scale modules with efficiencies of $11 \%$ have been demonstrated $[1,2]$. However, the performance of CdTe cells has been limited by the conventional polycrystalline $\mathrm{CdS} / \mathrm{CdTe}$ device structure. In the CdTe device, the poly-CdS film has been most commonly used as a window material. But it has two main issues that limit device performance. First, poly-CdS film has a bangap of $\sim 2.42 \mathrm{eV}$, which causes considerable absorption in the short-wavelength region. Higher $\mathrm{J}_{\mathrm{sc}}$ can be achieved by reducing the CdS thickness to improve the blue spectral response. However, reducing the CdS thickness can adversely impact device $V_{o c}$ and FF. We have previously reported that by integrating a high-resistivity zinc stannate (ZTO) buffer layer between the poly-CdS and poly-CdTe films, we can minimize these detrimental effects $[3,4]$. The best way to solve this issue should be to find a new window material with a higher optical bandgap than the poly-CdS film. Second, there is a nearly $10 \%$ lattice mismatch between the poly-CdTe film and the poly-CdS film, which causes the high defect density at the junction region. To reduce the lattice mismatch between the CdS and CdTe films, high- temperature device fabrication processes must be used to enhance the interdiffusion of the CdS and CdTe films and form an intermixed layer $\left(\mathrm{CdTe}_{1-\mathrm{x}} \mathrm{S}_{\mathrm{x}}\right)$. But during the hightemperature processes, new defects and impurities are introduced that limit the improvement of device $V_{o c}$ and FF. Therefore, a new window material that has both the higher optical bangap and a better lattice match with the CdTe absorber is an important project for further improving CdTe cell performance.

Several groups have developed new window materials with higher optical bandgaps than poly-CdS film, such as: $\mathrm{ZnSe}(2.69 \mathrm{eV}), \mathrm{ZnS}(3.70 \mathrm{eV})$, and $\mathrm{Zn}_{\mathrm{x}} \mathrm{Cd}_{1-\mathrm{x}} \mathrm{S}$ (2.42-3.70 eV) prepared by metal-organic chemical vapor deposition, spray pyrolysis, chemical bath deposition, sputtering, and screen-printing [5-10]. When using these window materials to replace the poly-CdS film, most device results show that $V_{o c}$ and $F F$ are reduced while $J_{s c}$ is improved. An explanation for this could be that these new poly window materials not only have higher bandgaps, but also have larger lattice mismatches to CdTe film than the poly-CdS film.

In this paper, we report a novel window material: oxygenated amorphous CdS film (a-CdS:O) prepared at room temperature by rf sputtering. The a-CdS:O film has a higher optical bandgap than the poly-CdS film and an amorphous structure. The preliminary device results demonstrated that $\mathrm{J}_{\mathrm{sc}}$ of the CdTe device can be greatly improved while maintaining higher $\mathrm{V}_{\mathrm{oc}}$ and FF.

\section{EXPERIMENTAL}

CdS films were prepared by rf magnetron sputtering at room temperature. The sputtering was carried out in a modified CVC SC-3000 system, evacuated to a base pressure of $\sim 2-3 \times 10^{-6}$ torr and then backfilled with an oxygen/Argon gas mixture at different ratios. Here, we refer to the $\mathrm{O}_{2} / \mathrm{Ar}$ ratio as the ratio of its flow rates. $A$ Corning 7059 glass substrate or glass/CTO $\left(\mathrm{Cd}_{2} \mathrm{SnO}_{4}\right) / \mathrm{ZTO}$ stack was placed on a sample holder parallel to the target surface. The distance between the substrate and the target was varied from 6 to $9 \mathrm{~cm}$. In this study, we used a commercial hot-pressed CdS target with $99.99 \%$ purity. Depositions were performed at an $\mathrm{O}_{2} / \mathrm{Ar}$ partial pressure of $10-20 \times 10^{-3}$ torr with rf power between 50-70 watts, providing a deposition rate of 5-10 $\AA / \mathrm{sec}$.

Five sputtered CdS samples (marked as sample \#1-\#5) were deposited at $\mathrm{O}_{2} / \mathrm{Ar}$ ratios of $0,1 \%, 2 \%, 3 \%$ and $5 \%$, respectively, on Corning 7059 glass substrates 
and used for material property characterizations. The electrical, optical, compositional, structural, and morphological properties of the a-CdS:O film were characterized using a Keithley 6517A electrometer, Cary 5 spectrophotometer, X-ray photoemission spectroscopy (XPS), X-ray diffraction (XRD), Raman spectra, and atomic force microscopy (AFM).

\section{MATERIAL PROPERTIES}

\section{Compositional analysis (XPS data)}

Table 1 lists oxygen atomic concentrations of sputtered films deposited at different $\mathrm{O}_{2} / \mathrm{Ar}$ ratios. We observe that the oxygen atomic concentration in CdS films increases with increasing $\mathrm{O}_{2} / \mathrm{Ar}$ ratio. Higher oxygen atomic concentration in CdS film can help to reduce Te diffusion from the CdTe to CdS film, thereby improving device $J_{s c}$ and efficiency $[11,12]$.

Table 1. The oxygen atomic concentration of sputtered $\mathrm{CdS}$ films deposited at different $\mathrm{O}_{2} / \mathrm{Ar}$ ratios.

\begin{tabular}{|c|c|c|}
\hline Sample & $\mathrm{O}_{2} / \mathrm{Ar}(\%)$ & $\mathrm{O}$ (at.\%) \\
\hline 1 & 0 & 4.35 \\
\hline 2 & 1 & 8.66 \\
\hline 3 & 2 & 11.08 \\
\hline 4 & 3 & 13.88 \\
\hline 5 & 5 & 22.73 \\
\hline
\end{tabular}

\section{Structural property}

Figure 1 shows XRD patterns of sputtered-CdS films deposited at different $\mathrm{O}_{2} / \mathrm{Ar}$ ratios. It can be seen that sample \#1, deposited in pure Ar, exhibits a polycrystalline structure with the preferential orientation along the (002) axis. The intensity of the (002) peak is reduced with the increase of the $\mathrm{O}_{2} / \mathrm{Ar}$ ratio (see sample \#2), then it disappears when the $\mathrm{O}_{2} / \mathrm{Ar}$ ratio increase to $2 \%$ or more. The CdS films, deposited at $2 \%$ or higher $\mathrm{O}_{2} / \mathrm{Ar}$ ratio, have an amorphous structure.

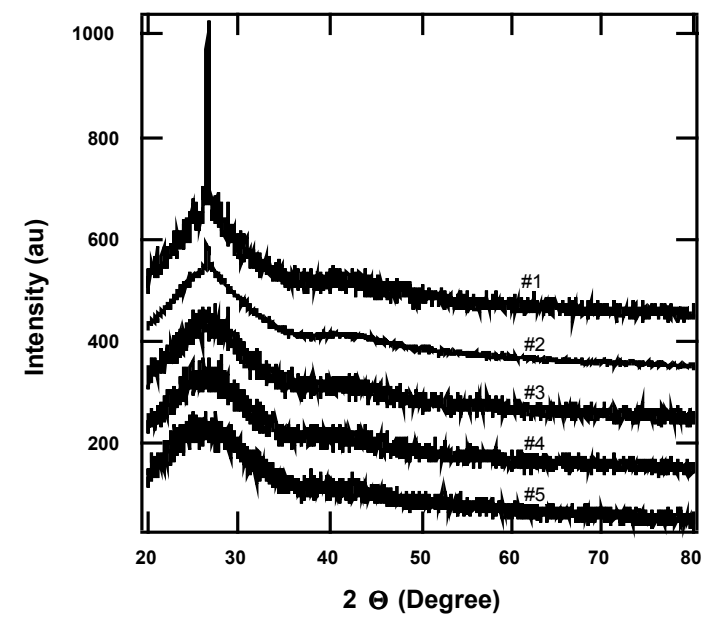

Figure 1. X-ray diffraction patterns of sputtered CdS films deposited at different $\mathrm{O}_{2} / \mathrm{Ar}$ gas ratios.

The results of Raman spectra measurements provide more detailed information on the structural property of these sputtered CdS films (see Figure 2). Figure 2(a) shows that with the increase of oxygen atomic concentration: (1) Raman peak intensity decreases, (2) Raman peak width broadens, and (3) Raman peak shifts to higher frequency, revealed in different orders of Raman transitions. Figure 2(b) also shows that on increasing oxygen atomic concentration: (1) CdS LO phonon frequency increases due to the incorporation of oxygen into the CdS films, and (2) Raman intensity decreases due to the reduction in volume of the crystalline CdS.
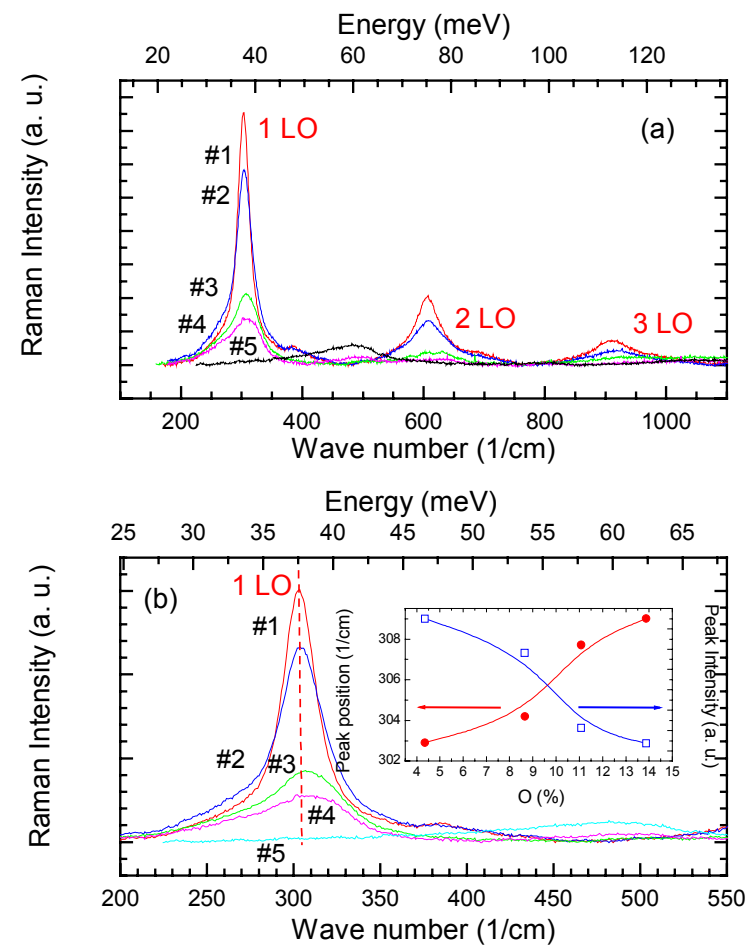

Figure 2. Raman spectra of sputtered CdS films deposited at different $\mathrm{O}_{2} / \mathrm{Ar}$ gas ratios.

\section{Grain size and surface roughness (AFM data)}

The grain size and average surface roughness of two samples have been measured by AFM. The results demonstrate that sample \#1, deposited in pure Ar, has a polycrystalline structure with grain size of about a few hundred $\AA$ and average surface roughness of $\sim 15 \AA$. In contrast, sample \#3, deposited in $2 \% \mathrm{O}_{2} / \mathrm{Ar}$ ambient, demonstrates an amorphous structure and has an extremely smooth surface with average surface roughness of $\sim 3 \AA$.

\section{Electrical properties}

Table 2 lists light conductivities $\left(\sigma_{\mathrm{L}}\right)$, dark conductivities $\left(\sigma_{D}\right)$, and photoconductivity ratios $\left(\sigma_{L} / \sigma_{D}\right)$ of sputtered CdS films deposited at different $\mathrm{O}_{2} / \mathrm{Ar}$ gas ratios. We can see from Table 2 that the maximum photoconductivity ratio of about 1000 is observed in sample \#3 and \#4, deposited at $2 \%$ and $3 \% \quad \mathrm{O}_{2} / \mathrm{Ar}$ gas ratios, respectively. The amorphous CdS films (sample \#3 and \#4) with high photoconductivity ratios are suitable as a window layer in polycrystalline CdTe devices. 
Table 2. Electrical properties of sputtered CdS films deposited in different $\mathrm{O}_{2} / \mathrm{Ar}$ gas mixtures.

\begin{tabular}{|c|c|c|c|c|}
\hline $\begin{array}{c}\text { Sample } \\
\#\end{array}$ & $\begin{array}{c}\mathrm{O}_{2} / \mathrm{Ar} \\
(\%)\end{array}$ & $\begin{array}{c}\sigma_{\mathrm{D}} \\
(1 / \Omega \mathrm{cm})\end{array}$ & $\begin{array}{c}\sigma_{\mathrm{L}} \\
(1 / \Omega \mathrm{cm})\end{array}$ & $\begin{array}{c}\sigma_{\mathrm{L}} / \sigma_{\mathrm{D}} \\
(\%)\end{array}$ \\
\hline 1 & 0 & $8.2 \times 10^{-1}$ & $2.8 \times 10^{-5}$ & 34 \\
\hline 2 & 1 & $2.2 \times 10^{-8}$ & $8.3 \times 10^{-6}$ & 377 \\
\hline 3 & 2 & $2.7 \times 10^{-9}$ & $2.6 \times 10^{-6}$ & 963 \\
\hline 4 & 3 & $6.3 \times 10^{-10}$ & $6.3 \times 10^{-1}$ & 1000 \\
\hline 5 & 5 & $4.3 \times 10^{-9}$ & $1.2 \times 10^{-1}$ & 30 \\
\hline
\end{tabular}

\section{Optical properties}

The optical measurement results demonstrate that the optical bandgaps of sputtered film increase with the increase of $\mathrm{O}_{2} / \mathrm{Ar}$ ratio (see Table 3 ). The amorphous CdS films (such as sample \#3, \#4, and \#5) have higher bandgap than poly-CdS (such as sample \#1), which can greatly help to improve device $J_{s c}$ and efficiency.

Table 3. Optical bandgaps of sputtered CdS films deposited at different $\mathrm{O}_{2} /$ Ar gas mixtures.

\begin{tabular}{|c|c|c|}
\hline Sample \# & $\begin{array}{c}\mathrm{O}_{2} / \mathrm{Ar} \\
(\%)\end{array}$ & $\begin{array}{c}\text { Optical bandgap } \\
(\mathrm{eV})\end{array}$ \\
\hline 1 & 0 & 2.42 \\
\hline 2 & 1 & 2.52 \\
\hline 3 & 2 & 2.65 \\
\hline 4 & 3 & 2.80 \\
\hline 5 & 5 & 3.17 \\
\hline
\end{tabular}

\section{DEVICE RESULTS AND ANALYSIS}

A limited number of CdTe cells, with a modified CTO/ZTO/a-CdS:O/CdTe device structure were prepared for demonstrating the application of a-CdS:O films. CTO transparent conductive oxide (TCO) films and ZTO buffer layers were deposited in pure oxygen at room temperature, as previously described $[1,4]$. The CdS films were deposited in a $2 \% \mathrm{O}_{2} / \mathrm{Ar}$ gas mixture. The $\mathrm{CdTe}$ films were prepared by the close-spaced sublimation (CSS) technique and were deposited at $570^{\circ}-630^{\circ} \mathrm{C}$ for $3-5 \mathrm{~min}$. After CSS deposition of the CdTe, the substrates were treated in $\mathrm{CdCl}_{2}$ vapor at $400^{\circ}-430^{\circ} \mathrm{C}$ for $15 \mathrm{~min}$. HgTe:CuTe-doped graphite paste, followed by a layer of Ag paste, was then applied to the devices as the backcontact layer.

We fabricated a number of CTO/ZTO/a-CdS:O/CdTe cells with NREL-confirmed efficiencies of more than $15 \%$ (see Table 4). It can be seen that when using an a-CdS:O film as the window layer, $J_{\text {sc }}$ of the CdTe device can be greatly improved while maintaining higher $\mathrm{V}_{\mathrm{oc}}$ and $\mathrm{FF}$, due to its high bandgap and amorphous structure.

Table 4. High-efficiency CTO/ZTO/a-CdS:O/CdTe cells

\begin{tabular}{|c|c|c|c|c|c|}
\hline $\begin{array}{c}\text { Cell } \\
\#\end{array}$ & $\begin{array}{c}\mathrm{V}_{\mathrm{oc}} \\
(\mathrm{mV})\end{array}$ & $\begin{array}{c}\mathrm{J}_{\mathrm{sc}} \\
\left(\mathrm{mA} / \mathrm{cm}^{2}\right)\end{array}$ & $\begin{array}{c}\mathrm{FF} \\
(\%)\end{array}$ & $\begin{array}{c}\eta \\
(\%)\end{array}$ & $\begin{array}{c}\text { Area } \\
\left(\mathrm{cm}^{2}\right)\end{array}$ \\
\hline 1 & 828.9 & 25.49 & 71.47 & 15.0 & 1.119 \\
\hline 2 & 828.5 & 24.58 & 73.97 & 15.1 & 1.011 \\
\hline 3 & 830.8 & 24.55 & 73.79 & 15.1 & 1.225 \\
\hline 4 & 832.2 & 24.68 & 74.03 & 15.2 & 1.083 \\
\hline 5 & 821.1 & 25.71 & 72.55 & 15.3 & 1.166 \\
\hline 6 & 832.4 & 25.85 & 71.77 & 15.4 & 1.056 \\
\hline 7 & 837.1 & 24.36 & 75.30 & 15.4 & 1.137 \\
\hline
\end{tabular}

In Fig. 3, we have demonstrated the relative internal quantum efficiency of a CTO/ZTO/a-CdS:O/CdTe cell with an NREL-confirmed total-area efficiency of $15.4 \%$ $\left(\mathrm{V}_{\mathrm{oc}}=832.4 \mathrm{mV}, \mathrm{J}_{\mathrm{sc}}=25.85 \mathrm{~mA} / \mathrm{cm}^{2}, \mathrm{FF}=71.77 \%\right.$, and Area $=1.056 \mathrm{~cm}^{2}$ ).

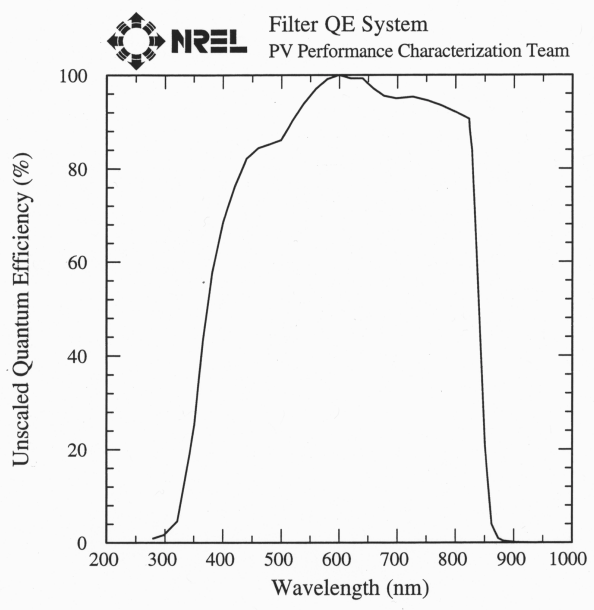

Figure 3. Relative internal quantum efficiency of a CTO/ZTO/a-CdS:O/CdTe thin-film solar cell.
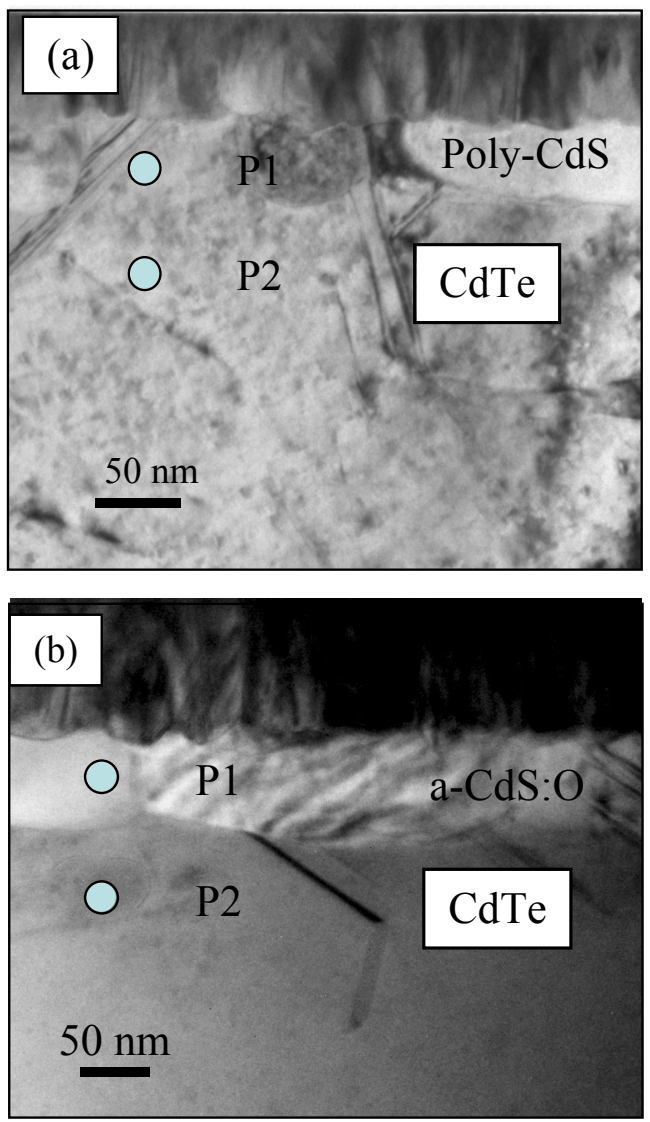

Figure 4. Cross-sectional TEM images of a polyCdS/CdTe cell (a) and an a-CdS:O/CdTe cell (b). 

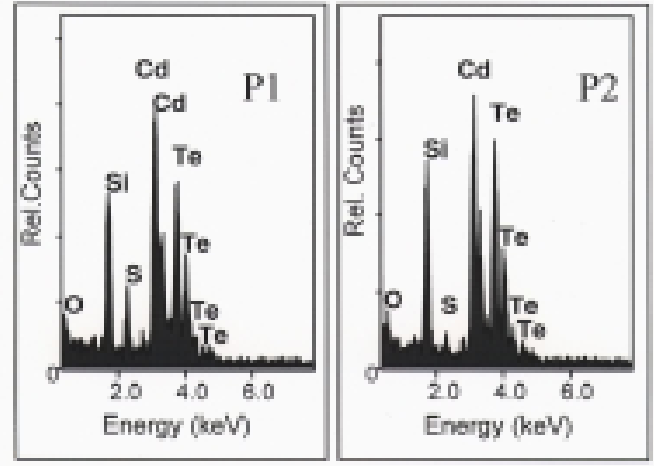

(a)

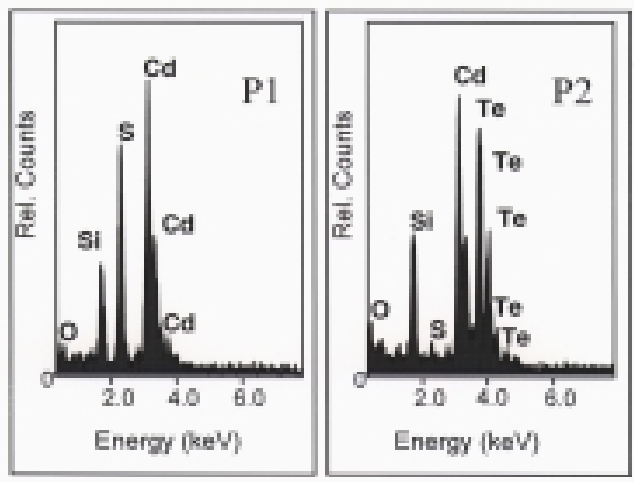

(b)

Figure 5. EDS (a) and (b) taken from points $\mathrm{P} 1$ and P2 marked on Fig. 4(a) and Fig. 4(b), respectively.

It can be seen from Fig. 3 that this cell with $\sim 1100 \AA$ aCdS:O film still has high blue quantum efficiency (QE) and high $\mathrm{J}_{\mathrm{sc}}$. We have done transmission electron microscopy (TEM) and energy-dispersive spectroscopy (EDS) measurements to explain why this cell with a thicker CdS film has high blue $Q E$ and $J_{\text {sc. }}$.

Figures 4 (a) and 4(b) show cross-sectional TEM images of a poly-CdS/CdTe cell (a) and an a-CdS:O/CdTe cell (b). In the poly-CdTe cell, the CdS film with a polycrystalline structure was deposited in pure Ar by if sputtering. In Fig. 4(a), the CdS layer is not visible in some regions, which indicates total consumption of the CdS film. In some areas, the CdS is seen, but with significantly decreased thickness, suggesting that the CdS consumption is spatially variable in the plane of the film. The EDS measurement results (see Fig 5(a)) also indicate Te diffusion into the CdS layer (point P1 in Fig. 5(a)). Optical bowing in the $\mathrm{CdS}_{\mathrm{x}} \mathrm{Te}_{1-\mathrm{x}}$ alloy system is such that small changes in the Te content of CdS can result in a large decrease in bandgap [13, 14]. The formation of $\mathrm{CdS}_{\mathrm{x}} \mathrm{Te}_{1-\mathrm{x}}$ alloy having a lower bandgap results in poor quantum efficiency in the short-wavelength region. In contrast, it can be seen that the a-CdS:O layer is still very visible (see Fig. 4(b)). The a-CdS:O film has much higher oxygen atomic concentration than poly-CdS film (see Table 1). Therefore, this strongly indicates that oxygen present in a-CdS:O films significantly suppresses the Te interdiffusion from the CdTe to the CdS film and the formation of a CdS $\mathrm{Te}_{1-\mathrm{x}}$ alloy. The EDS results (see Fig. 5(b)) also confirm that Te cannot be found in the a-CdS:O layer (point P1 in Fig. 5(b)), which results in a high QE in the short-wavelength region (see Fig. 3 ) and a high $\mathrm{J}_{\mathrm{sc}}$.

\section{CONCLUSIONS}

We have developed a process for preparing the oxygenated amorphous CdS window material (a-CdS:O) at room temperature by if sputtering. The a-CdS:O films have a higher optical bandgap (2.5-3.1 eV) than poly-CdS film and an amorphous structure, which result from its higher oxygen atomic concentration. The higher $\mathrm{O}$ content presented in the a-CdS:O films can significantly suppress the Te diffusion from the CdTe into the CdS film and the formation of a $\mathrm{CdS}_{x} \mathrm{Te}_{1-\mathrm{x}}$ alloy. When integrating the a-CdS:O film into $\mathrm{CdTe}$ cell, the $\mathrm{J}_{\mathrm{sc}}$ can be greatly improved while maintain higher $\mathrm{V}_{\mathrm{oc}}$ and FF. A CdTe cell demonstrating an NREL-confirmed $\mathrm{J}_{\mathrm{sc}}$ of $25.85 \mathrm{~mA} / \mathrm{cm}^{2}$ and a total-area efficiency of $15.4 \%$ has been achieved.

\section{ACKNOWLEDGMENTS}

The authors would like to thank D. Albin, T. Gessert, J. Keane, K. Ramanathan, D. Dunlavy, T. Moriarty, K. Emery, B. Keyes, L. Gedvilas, S. Yoon, H.R. Moutinho, Q. Wang, D. Levi, S. Asher, K. Zweibel, P. Sheldon, and J. Benner for their contributions and great support.

This work is supported by the U.S. Department of Energy under Contract No. DE-AC36-99G010337 to NREL.

\section{REFERENCES}

[1] X. Wu et al., Proc of $17^{\text {th }}$ European PVSEC, (2001).

[2] D. Cunningham et al., Proc. of $28^{\text {th }}$ IEEE PVSC, pp. 13$18(2000)$.

[3] X. Wu et al., J Applied Physics, 89, No. 8, pp. 45644569 (2001).

[4] X. Wu et al., Proc. of $28^{\text {th }}$ IEEE PVSC, pp. 470-474 (2000).

[5] T.L. Chu et al., J Applied Physics, 71, pp. 3865-3869 (1992).

[6] C.S. Ferekides et al., Proc. of $13^{\text {th }}$ NREL PV program Review Meeting, pp. 39 (1995).

[7] Shaiw-Yih Yin et al., J Applied Physics, 49 (3), pp. 1294 (1978).

[8] N. Suyama et al., Proc. of $19^{\text {th }}$ IEEE PVSC, pp. 1470 (1987).

[9] T.L. Chu et al., J Applied Physics, 70, pp. 2688 (1991).

[10] I.O. Oladeji et al., Solar Energy Materials \& Solar Cells, 61, pp. 203 (2000).

[11] Y. Yan et al., Proc. of NREL/SNL PV Program Review Meeting, (2001).

[12] D.S. Albin et al., Prog. Photovoltaics: Res. Appl. (in press) (2002).

[13] K. Ohata et al., Japan. J. Appl. Phys, 12 (10), pp.1641 (1973).

[14] S. Wei et al., J Applied Physics, 87 (3), pp. 1304 (2000). 


\section{REPORT DOCUMENTATION PAGE}

Form Approved OMB NO. 0704-0188

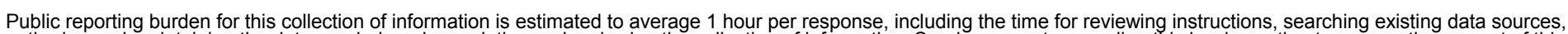

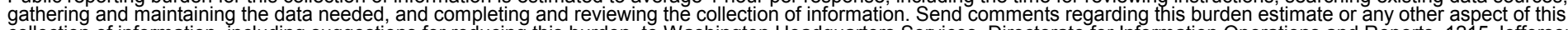

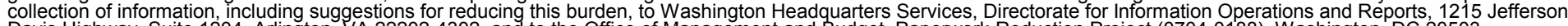

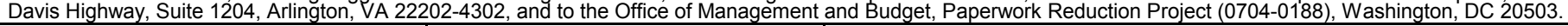

1. AGENCY USE ONLY (Leave blank) 2. REPORT DATE May 2002

\section{REPORT TYPE AND DATES COVERED} $29^{\text {th }}$ IEEE PVSC-Conference Paper May 20-24 2002

4. TITLE AND SUBTITLE High-Efficiency Polycrystalline CdTe Thin-Film Solar Cells with an Oxygenated Amorphous CdS (a-CdS:O) Window Layer: Preprint

6. Author(S)

X. Wu, R.G. Dhere, Y. Yan, M.J. Romero, Y. Zhang, J. Zhou, C. DeHart, A. Duda, C. Perkins, and B. To

7. PERFORMING ORGANIZATION NAME(S) AND ADDRESS(ES) National Renewable Energy Laboratory 1617 Cole Blvd.

Golden, CO 80401-3393

9. SPONSORING/MONITORING AGENCY NAME(S) AND ADDRESS(ES) National Renewable Energy Laboratory 1617 Cole Blvd.

Golden, CO 80401-3393
5. FUNDING NUMBERS PVP14201
8. PERFORMING ORGANIZATION REPORT NUMBER

11. SUPPLEMENTARY NOTES

12a. DISTRIBUTION/AVAILABILITY STATEMENT National Technical Information Service

12b. DISTRIBUTION CODE

U.S. Department of Commerce

5285 Port Royal Road

Springfield, VA 22161

13. ABSTRACT (Maximum 200 words): In the conventional CdS/CdTe device structure, the poly-CdS window layer has a bandgap of $\sim 2.4 \mathrm{eV}$, which causes absorption in the short-wavelength region. Higher short-circuit current densities $\left(\mathrm{J}_{\mathrm{sc}}\right)$ can be achieved by reducing the CdS thickness, but this can adversely impact device open-circuit voltage ( $\left.V_{\text {oc }}\right)$ and fill factor (FF). Also, polyCdS film has about $10 \%$ lattice mismatch related to the CdTe film, which limits the improvement of device $V_{\text {oc }}$ and $F F$. In this paper, we report a novel window material: oxygenated amorphous CdS film (a-CdS:O) prepared at room temperature by rf sputtering. The a-CdS:O film has a higher optical bandgap (2.5-3.1 eV) than the poly-CdS film and an amorphous structure. The preliminary device results have demonstrated that $\mathrm{J}_{\mathrm{sc}}$ of the CdTe device can be greatly improved while maintaining higher $\mathrm{V}_{\mathrm{oc}}$ and FF. We have fabricated a CdTe cell demonstrating an NREL-confirmed $\mathrm{J}_{\mathrm{sc}}$ of $25.85 \mathrm{~mA} / \mathrm{cm}^{2}$ and a total-area efficiency of $15.4 \%$.

14. SUBJECT TERMS: PV; oxygenated amorphous CdS; high-efficiency polycrystalline; thinfilm solar cells; short-wavelength region; cadmium telluride (CdTe); photoemission spectroscopy (XPS); X-ray diffraction; Raman spectra; atomic force microscopy (AFM)

17. SECURITY CLASSIFICATION OF REPORT Unclassified
18. SECURITY CLASSIFICATION OF THIS PAGE Unclassified
19. SECURITY CLASSIFICATION OF ABSTRACT Unclassified
15. NUMBER OF PAGES

16. PRICE CODE

20. LIMITATION OF ABSTRACT

UL

NSN 7540-01-280-5500

Standard Form 298 (Rev. 2-89) Prescribed by ANSI Std. Z39-18 